\title{
Erythropoietin and iron: separating the builder from his blocks
}

\author{
Sandaruwani Abeysiri, MBBS, MSc (1) - Marisa Chau, BSc • \\ Toby Richards, MD, FRSC
}

Received: 3 September 2019/Revised: 9 September 2019/Accepted: 10 September 2019/Published online: 21 October 2019

(C) Canadian Anesthesiologists' Society 2019

\section{To the Editor,}

We read with interest the recently published systematic review on safety and efficacy of erythropoietin and iron therapy in surgical patients. ${ }^{1}$ Nevertheless, we question as to whether the authors are correct to place these two interventions together.

Erythropoietin is a hormone for erythropoiesis-i.e., it is the builder of red blood cells. On the other hand, iron is a substrate for haemoglobin-i.e., it is a building block. In combination, intravenous iron increases the effectiveness of erythropoiesis-stimulating agents (ESAs) ${ }^{2}$-i.e., the builder supplied with sufficient building blocks can then work effectively. Conversely, ESAs do not work if the underlying problem is iron deficiency, ${ }^{3}$ and giving intravenous iron alone does not lead to polycythemia. ${ }^{4}$

In the meta-analysis by Kei et al., ${ }^{1}$ there is no mention of the patient iron status. Furthermore, non-anemic populations were also included, where we can infer that the majority ( $>75 \%$ ) of the study populations may be iron replete. $^{5}$ Therefore, intravenous iron has no role in these patients and would not be expected to change the primary endpoint reported in the meta-analysis. The analysis may therefore be confounded.

The interpretation of these data would be enhanced by knowing what were the outcomes and analyses for those

This letter is accompanied by a reply. Please see Can J Anesth 2020; 67: this issue.

S. Abeysiri, MBBS, MSc $(\square) \cdot$ M. Chau, BSc

University College London, London, UK

e-mail: s.abeysiri@ucl.ac.uk

T. Richards, MD, FRSC

University of Western Australia, Perth, Australia patients for whom iron therapy was actually clinically indicated.

Conflicts of interest None declared.

Editorial responsibility This submission was handled by Dr. Hilary P. Grocott, Editor-in-Chief, Canadian Journal of Anesthesia.

\section{References}

1. Kei T, Mistry N, Curley $G$, et al. Efficacy and safety of erythropoietin and iron therapy to reduce red blood cell transfusion in surgical patients: a systematic review and metaanalysis. Can J Anesth 2019; 66: 716-31.

2. Roger SD. Practical considerations for iron therapy in the management of anaemia in patients with chronic kidney disease. Clin Kidney J 2017; DOI: https://doi.org/10.1093/ckj/sfx100.

3. Karlsson T. Effects of iron supplementation on erythropoietic response in patients with cancer-associated anemia treated by means of erythropoietic stimulating agents. ISRN Hematol 2011; DOI: https://doi.org/10.5402/2011/108397.

4. Clevenger B, Richards T. Pre-operative anaemia. Anaesthesia 2015; DOI: https://doi.org/10.1111/anae.12918.

5. Wu YG, Zeng $Y$, Shen B, et al. Combination of erythropoietin and tranexamic acid in bilateral simultaneous total hip arthroplasty: a randomised, controlled trial. HIP Int 2016; DOI: https://doi.org/10. 5301/hipint.5000356.

Publisher's Note Springer Nature remains neutral with regard to jurisdictional claims in published maps and institutional affiliations. 